\title{
Contested externalisation: responses to global inequalities
}

Thomas Faist

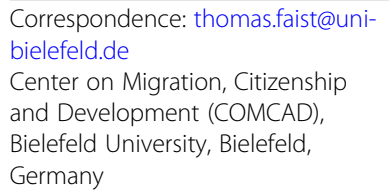

Correspondence: thomas.faist@unibielefeld.de

Center on Migration, Citizenship and Development (COMCAD), Bielefeld University, Bielefeld, Germany

\begin{abstract}
What is new about contemporary remote control across borders? An important element is the reference to human rights norms by various political actors such as NGOs, migrant associations but also national governments, international organisations and an activist judiciary. It is evident that externalisation policies mirror stark power asymmetries of the global and regional political orders, and thus reflect social inequalities more generally. The contestation around externalized migration control has gone through several periods. Integral to an understanding of control are the practices of migrants themselves, how they seek to circumvent controls or even resist. Thinking further ahead, we may conceive of the border as a paradox, involving both connecting and separating humans and artefacts. Such an understanding of border allows for the possibility of coexistence; difference between two or more entities being a requirement. The border does not belong to either side. How to imagine such a type of border between states is a formidable challenge to social theory.
\end{abstract}

Keywords: Externalization, Border(s), Social and global inequalities, Migration control

Externalisation policies or, as they are sometimes called, forward or remote control policies, are not entirely new. Visa policies, for example, were used by US authorities in granting access to the territory in the late nineteenth century and early 20th centuries to prospective European emigrants on their way to the Americas (Zolberg, 2006, pp. 11, 110-13, 240-41). So the question is: what is new about contemporary remote control? An important element of today's externalisation efforts is the reference to human rights norms by various political actors such as NGOs, migrant associations but also national governments, international organisations and an activist judiciary. In a nutshell, human rights have entered the realms of international mobility and border control increasingly since the late 1970s when it comes to evaluating social orders as legitimate or illegitimate (cf. Moyn, 2010). Struggles around human rights have been among the most contentious issues of externalisation policies and their consequences. Externalisation of control is part of a general trend which has made borders ubiquitous by extending the reach of control both spatially and institutionally, both within states and beyond. It is evident that externalisation policies mirror stark power asymmetries of the global and regional political orders, and thus reflect social inequalities more generally. Nonetheless, the crucial question - and the focus of this special issue - is how the discontents have been voiced and have resulted in corresponding responses to measures imposed by regional powers such as the EU upon its close and distant neighbours.

(c) The Author(s). 2019 Open Access This article is distributed under the terms of the Creative Commons Attribution 4.0 International License (http://creativecommons.org/licenses/by/4.0/), which permits unrestricted use, distribution, and reproduction in any medium, provided you give appropriate credit to the original author(s) and the source, provide a link to the Creative Commons license, and indicate if changes were made. 


\section{The contested realms of border control: three stages and no end in sight}

Following the past four decades, three periods in the politics of human rights in externalisation efforts can be distinguished, largely driven by an endogenous dynamic. The first period saw the emergence of the liberal paradox in the 1970s: the human rights of noncitizen migrants became more prominent in contradistinction to sovereign national state interests which until then had not taken into consideration basic rights to, for example, emergency health care. The second period was mainly characterised by the externalisation of migration and border policies on the part of actors such as the EU and its member states, which tried to offload the costs of control to countries of origin and transit. These externalisation policies have been meant to circumvent the liberal paradox by trying to prevent migrants from reaching the territories of immigration states in the first place. Restrictive visa policies, adoption of EU-compatible control policies in countries of origin and transit, detention camps for those migrants just outside the borders and deportation procedures aimed at those undesirables who made it into immigration states have been among the characteristic measures. Yet there has been a counter-movement, driven by NGOs and national, inter- and supra-national courts, which criticised these policies and ruled in favour of human rights norms to be applied everywhere, at least in principle (Dembour, 2015). Finally, the third period, which has been slowly emerging, is one in which European countries are engaging more directly with the states in the cordon sanitaire around Europe and even farther afield in states labelled as denoting the global South. Yet as amply demonstrated by the contributions to this issue (https://comparativemigrationstudies.springeropen.com/migrationpoliciesglobalsouth), these states are not simply passive recipients of externalisation measures. Instead, such states are engaging in a sort of migration and border diplomacy with the EU (Üstübici, 2019).

Clearly, the three periods just sketched overlap, and are thus to be taken as a heuristic device to distinguish essential precedents, characteristics and consequences of externalisation policies. In a very general sense, once could say that, especially in the second and third periods, Foucault's relational power perspective is at work: "where there is power, there is resistance" (Foucault, 1976, p. 75). For our purposes this means that the dynamics of externalisation are driven by a web of power relations between the various political actors involved, encompassing above all governments, courts and activist NGOs. Also, as amply demonstrated by all the contributions in this issue (https://comparativemigrationstudies.springeropen.com/migrationpoliciesglobalsouth), on a micro-level migrants are crucial players in circumventing and sometimes resisting externalisation policies.

The first period was not one of externalisation but rather of internalisation, namely the integration of human rights within applied law of liberal democratic national states. It was only in the latter part of the 1970s that immigration states in Europe started to pay more attention to fundamental (human) rights for non-citizens. One of the path-breaking decisions involved was the by-now famous "Indian case" in 1978 in Germany. In this case, the Federal Constitutional Court decided that a non-German citizen-an Indian nationalhad a right to a permanent residence permit, based on his previous employment history (Triadafilopoulos, 2012, p. 122). This more straightforward consideration of human rights created a liberal dilemma. According to this dilemma, most liberal democracies have, on the one hand, undertaken obligations to honour human rights conventions, such as the Geneva Convention on Refugees, and to extend fundamental rights even to non-citizen populations on their territory (cf. Hollifield, 2004). On the other hand, these democracies 
seek to restrict the large-scale entry of migrants and refugees because of-among other reasons-security concerns, contentious politics around welfare state resources and regulations, and issues that are labelled cultural conflicts centred on religion and ways of life. Once forced migrants reach the territories of liberal democracies, the likelihood of their staying is rather high, thanks to human rights norms, even in the case of non-recognition as asylum seekers.

Through a sort of forward or remote control as part of externalisation policies, migrants do not even reach the territory of the immigration countries and, therefore, the liberal dilemma does not arise. An important specific reason can be found in the non-refoulement principle enshrined in the Geneva Convention on Refugees (Article 33), which states that asylum seekers cannot be returned to countries where they face life-threatening circumstances. Not surprisingly, it is against this background that externalisation is an attractive policy choice for destination countries to separate desirable from undesirable migrants already in the regions of origin and transit.

Efforts to circumvent the liberal dilemma thus ushered in the second period, that of externalisation proper. Here, three examples are sketched: visa policies, extra-territorial zones and push-back at sea. The first one-visa policies-has been largely effective but with unintended consequences (Laube, 2019). The second and third options are crucial from another angle: they have been criticised and brought to court by NGOs (Leisering, 2016). As to the first option, the concept that visa policies could function to outsource migration control was not well established. In the early 1990s the EU began its efforts to control its outer borders by vetting potential migrants in their countries of origin through visa requirements and checks at points of embarkation. The visa system and the Schengen requirements produce precisely the illegal practices of accessing visas that they are presumably meant to forestall (Ambrosini, 2017). At the very least, one might argue, what we see are the unintended consequences of externalisation and securitisation (Faist, 2019, chapter 7): Militarised borders between but also within African countries create higher risks for migrants, who in turn have to invest more resources to overcome these obstacles. Part of the process is the professionalisation of smuggling networks-more profit could be made but the journeys also became more dangerous. A case in point is Agadez in Niger, one of the hubs of travel from South to North in Africa. The original smugglers were displaced by a new group of smugglers who nowadays take even more insecure roads through the Sahara to avoid border controls. In due course the Sahara has developed, as did the Mediterranean, into a 'mass grave' or a 'cemetery' (Brachet, 2018). In short, the control policies designed to reduce the dangers of illegal migration turned into drivers of the very process they are meant to combat.

Second, also as a response to the liberal dilemma, state authorities started to establish extra-territorial zones at points of entry into such states. The whole point of these zones is that-according to state authorities-human rights do not need to be observed. An example which gained some prominence was the extra-territorial zone at the Charles de Gaulle airport in Paris, run by the French border police for 10 years, starting in the 1980s. The authorities argued that human rights have to be observed only within the state's jurisdiction, which is congruent with the territory of the state. Oppositional NGOs, however, reported on the human rights violations, exerted public pressure on the respective authorities through mass media, and informed UN human rights observatories. But most important, NGOs brought the case to national and international courts. As a result, the national courts 
and the European Court on Human Rights (ECHR) concluded that the extra-territoriality claimed by the French authorities was simply a legal fiction. It ruled that there is no "legal no man's land," and that there is no extra-territorial space devoid of human rights for tourists, migrants and refugees (Kokott, 1997). We may interpret this development as a move toward de-territorialising human rights, that is, human rights are not tightly bound to the territorial reach of states although it is often the latter who usually enforce or violate these very rights.

The third example of externalisation measure concerns the push-back of vessels loaded with migrants from North Africa across the Mediterranean. The contested issue was whether human rights should be secured in international open sea. To an increasing degree, the legal opinion that human rights also apply in open sea-outside national territorial jurisdiction-has been voiced by the ECHR and expert committees of the UN since the 1970s. And it is since then that NGOs have intervened on a regular basis into border control regulations, e.g. Frontex. As a matter of fact, in the 2000s, Italian authorities tried to close off the central Mediterranean route from Libya to Italy. Again, NGOs went to court to have it confirmed that human rights apply everywhere, including in the open sea. In a decision by ECHR (2012, Hirsi Jamaa and others v. Italy), which concerned Somali and Eritrean migrants travelling from Libya who had been intercepted at sea by the Italian authorities and sent back to Libya, ECHR ruled that the push-back was contrary to human rights norms and amounted to "collective expulsion" (Dembour, 2012). In particular, the courts decided that state sovereignty is exerted when its servants exercise effective control. However, such decisions have not prevented the deaths of thousands of migrants and refugees in their efforts to cross the Mediterranean. A common element of the second and third options is that they depend on mobilising NGOs and a rather activist judiciary.

Far from being a thing of the past, the struggles around extra-territoriality and application of human rights standards and norms are ongoing. These very struggles, advanced by endogenous dynamics depending on mobilisation through social movements and NGOs and a liberal rule of law, may have set the stage for a third period, in which the states constituting-from a European perspective-a sort of cordon sanitaire have learned to adapt to externalisation policies and try to extract benefits for themselves. One indicator of this third period is, as all contributions to this special issue argue, that countries of origin and transit are not simply passive recipients of an overpowering EU imposing its norms upon them. There has been no straightforward imposition of EU conditionality on states in the cordon sanitaire, such as Morocco, Turkey or Moldova. These states are better described as being engaged in migration and border diplomacy; there is room for manoeuver and brokering. A clear example is the EU-Turkey Deal which corresponds to "an ENP-like accession partnership" (Karadağ, 2019). This means that this deal is functionally equivalent to the European Neighbourhood Policy (ENP) scheme. Through this agreement, the Turkish regime receives financial support, makes itself indispensable for EU border policy, and has been able to position itself in a selfconscious way vis-à-vis the EU, plausibly demanding visa liberalisation (so far unsuccessfully). Is there already a sort of "reverse conditionality," that is, transit and origin states pushing their own agenda? (Laube, 2019). What is certain is that the EU Commission has used various circles of externalisation: a first circle is constituted by countries with whom the EU concluded the ENP, such as Moldova. With these states 
readmission agreements and other forms of control have been achieved. A second circle is made up by Turkey and Morocco in their functions as 'gatekeepers' for the EU. The threat not to readmit and to wave through migrants to Europe is very credible in these two latter cases. A third circle, somewhat more distant geographically, is made up of those countries with whom Migration Partnerships were concluded in 2015: Senegal, Mali, Nigeria, Niger and Ethiopia. In these cases, bargaining over readmission and stopping unwanted migrants (from the point of view of the EU) have proven more contentious, and visa waivers for citizens of these countries to EU states are still far away. In this category, an expression of the contestation is the fact that the Malian government has refused twice to sign readmission agreements, with France in 2009 and with the EU in 2016/17 (Sylla \& Schultz, 2019).

Externalisation policies have consequences for how a human rights agenda or rightsbased agenda finds its way into the politics of transit and origin countries. Such policies focus on control and care in terms of short-term relief. This means, for example, that the EU Commission is focusing on short-term relief efforts which define migrants as victims, basically upholding the right to life but not other essential rights, such as the right to health care.

\section{Externalisation and its impact on internalisation}

The contributions to this issue (https://comparativemigrationstudies.springeropen.com/ migrationpoliciesglobalsouth) also point to the need to analyse various scales of institutions and practices. Integral to an understanding of control are the practices of migrants themselves, how they seek to circumvent controls or even resist (Tyzler, 2019; Vammen, 2019). All of the articles provide rich descriptions of resistance from below to externalised migration control; and they consider multiple levels of analysis, not only inter-state but also intra-state, transnational and cross-national. For example, civil society organizations in Mali, such as Afrique-Europe-Interact (AEI) and the Malian Association for Deportees (AME), condemned the Malian government for using tragic events, such as the death of many migrants in the Mediterranean near the Libyan coast in 2015, to observe a Day of National Mourning. Civil society organizations criticised the government's failure in bringing about economic development, which-in their view-underlie the high propensity to migration (Sylla \& Schultz, 2019). Another example is the agency exerted by black women who are often depicted as lacking the ability to resist, expressed as "migrantwomen-victim with no agency" (Tyzler, 2019). What can be clearly discerned, however, is the resistance of African women to hindered migration. The obstacles to overcome consist of not only formal border control but also control within the group of migrants. For example, there is male control among the migrants themselves through elders (e.g. "chairman"), who facilitate or block access at the border crossing points of Ceuta and Melilla. Black women use various methods of agency; for instance, pregnancy for women is a way to increase chances of rescue through the Spanish border police. The latter are more likely to save groups with women and children (Tyzler, 2019).

This last finding points to internal hierarchies in the category of mobile persons in at least two ways. First, migrants en route experience various forms of exclusion from onward journeys. For example, as just reported, gender-based exclusion and violence are operative in migrant camps in Morocco and throughout journeys. This finding suggests that the focus of this special issue on mechanisms of mobility and immobility en route 
which are based on categorisations along heterogeneities such as gender, age and citizenship is of utmost relevance. The task is to unveil the exact social mechanisms which are at work during the mobility trajectories (Faist, 2019: chapter 1). Second, as data on global income inequalities seem to indicate, it is mainly persons in the upper brackets of income in the world which has the material means to engage in long-distance travel (Korzeniewicz \& Moran, 2009). There is definitely a class-specificity in this kind of cross-border movement which has not been given due attention in research so far. To refer mainly to the smooth cross-border journeys of privileged strata, such as expatriates working in multinational companies v. (ir)regular migrants trying to make it on their own, mostly with the help of their families, is short-sighted. More attention needs to be paid to the strategies of those who are mobile across borders or even across continents in contrast to those who (have to) choose in situ adaptation in locales of origin and locales along their often stalled journeys (on immobility, see Hammar, Brochmann, Tamas, \& Faist, 1997).

\section{Negotiations over externalisation and internationalisation}

An open question is the nexus of outsourcing and insourcing of control policies in such cases: states that are not passive recipients of European or North American rules of control will also have room for manoeuver in dealing with migrants. Analysts have connected externalisation and internationalisation policies and responses with respect to European and North American contexts by viewing them as mirror images. In other words, remote control far afield is, for example, accompanied by rigorous surveillance by way of deportation and detention policies (Menjívar, 2014). When it comes to connecting externalisation and internationalisation in countries being depicted as origin or transit countries, research is much scarcer. Questions need to be asked about the practices of states waving migrants through their territories without much support in terms of security or basic social protection. While it is plausible to argue that migration control policies in the neighbourhood of Europe are primarily shaped by policies designed in the EU, political actors outside the EU-in countries of origin and transit migration to the EU in particular-decisively contribute through their actions to migrants' experience of cross-border mobility.

Since the main routes from North Africa to Europe have become more difficult to cross, transit countries such as Costa Rica and Argentina, for example, have experienced the passage (Costa Rica) or settlement (Argentina) of an increasing number of migrants from Africa. The externalisation of EU control policies has made migrants' journeys more turbulent, costly, and perilous-and has led to the emergence of new routes taken by African migrants. New routes have formed as alternatives to dangerous paths from Africa to Europe. For example, Argentina has become a destination, especially for migrants from Senegal; with migrants transiting countries such Brazil and Ecuador on their way to the Southern Cone (Vammen, 2019).

Countries of transit in Central and South America are far from "powerless pawns" (Winters \& Izaquirre, 2019) in the hands of the hegemonic country in the region, the USA. Costa Rica has pursued a comparatively humane approach to transit, making sure, for instance, that migrants can rest before continuing their onward journey north. At the same time, the pressures upon Central American countries to engage in securitised migration control policies has been immense although Costa Rica is relatively independent of US funding. Nonetheless, there have been zones of relative tolerance for transit migrants in countries such as Costa Rica. Ultimately, this double logic of 
care and control is indicative of the conflicting goals and expectations of actors seeking to adhere to humanitarian standards.

\section{Conclusion: the border as a paradox}

At the very least, this issue's (https://comparativemigrationstudies.springeropen.com/ migrationpoliciesglobalsouth) contributions suggest that borders have become ubiquitous, that they do not just represent territorial border lines but have been moving spatially into zones of transit and origin, and institutionally by the EU and its member states in transposing control policies upon transit and origin countries in exchange for financial aid. So the focus in this issue has been both on how migrants themselves have dealt with this extension of border zones or borderlands, and on how collective political actors such as civil society associations, governments and courts have become embroiled in contestations over border control. It is therefore worth probing into the multiple meanings given to borders. Borders are characterised by a certain degree of density of social relations and by the attribution of meaning. In this way, we may think of the cross-border spaces or borderlands as transnational social spaces. It is in these transnational spaces that conflicts over borders have played out.

Thinking further ahead, we may conceive of the border as a paradox, involving both connecting and separating humans and artefacts. According to George Simmel (1918/ 2001), human beings are quintessential "border figures "(Grenzwesen) and a person is a "connecting being who has to constantly separate and cannot connect without separating". In other words, first, borders connect what is separated: for example, transnational mobility may enable families to unite who lived previously on different sides of borders in different states. Second, borders separate what is connected: states (and in Africa, mostly colonial powers) superimposed border lines and often tightly control movements at, into and through their territories. At the same time, connecting what is separated serves as a meta-mechanism of integrating the populace into national states. In essence, the exclusion of non-citizens outside the territory of national states and the inclusion of citizens into an imagined national community are two sides of the same coin. In nuce, the border is a paradox, and contestations over borders have to take this paradox into consideration.

Certainly, borders between states and the concomitant border spaces and borderlands signal an unequal power relationship in a global social order characterised by manifold inequalities; the different value of citizenship, depending on the status of the country in the global hierarchy, is but one example. All of this is very different from an understanding of border which sees it as a hindrance that can indeed be overcome and traversed. In other words, traffic across the border is a requirement for its constitution. By implication, in this perspective a sharp delineation such as a wall is not really a border. An understanding of border which privileged the dialectics of simultaneous connectivity and separation actually existed in Europe until well into the 18th and 19th centuries, before the advent of nationalism. Border in this meaning is a demarcation line which allows two entities to live next to each other. To put it differently, a border allows for the possibility of coexistence; difference between the two entities being a requirement. The border does not belong to either side. Such a nowadays perhaps utopian concept of the border could be a way to recognize differences and heterogeneities of entities (which are also in flux), the condition being that the two (or more) sides are fairly equal with respect to their social status. How to imagine such a type of border between states is a formidable challenge to future social theory. 
Acknowledgements

The author would like to thank the editors of this special issue for their comments and suggestions.

\section{Author's contributions}

Thomas Faist is the sole author of this article. The author read and approved the final manuscript.

\section{Funding}

Not applicable.

\section{Availability of data and materials}

Not applicable

\section{Competing interests}

The author declares that he has no competing interests.

Received: 23 July 2019 Accepted: 16 September 2019

Published online: 02 December 2019

\section{References}

Ambrosini, M. (2017). Irregular immigration in southern Europe: Actors, dynamics and governance. Basingstoke: Palgrave Macmillan.

Brachet, J. (2018). Manufacturing smugglers: From irregular to clandestine mobility in the Sahara. Annals of the American Academy of Political and Social Science, 676(1), 16-35.

Dembour, M. B. (2015). When humans become migrants: Study of the European court of human rights with an inter-American counterpoint. Oxford: Oxford University Press.

Dembour, M.-B. (2012, March 1). Interception-at-sea: Illegal as currently practiced - Hirsi and Others v. Italy [Blog post]. Strasbourg Observers. Retrieved from https://strasbourgobservers.com/2012/03/01/interception-at-sea-illegal-as-currentlypracticed-hirsi-and-others-v-italy/.

ECHR (2012). Hirsi Jamaa and others v. Italy (Application no. 27765/09). Retrieved from https://hudoc.echr.coe.int/eng\#\{\%22 itemid\%22:[\%22001-109231\%22].

Faist, T. (2019). The transnationalized social question: Migration and the politics of social inequalities in the twenty-first century. Oxford: Oxford University Press.

Foucault, M. (1976). Truth and power. In C. Gordon (Ed.), Power/knowledge - Selected interviews and other writings 1972-1977, (pp. 134-145). New York: Pantheon Books.

Hammar, T., Brochmann, G., Tamas, K., \& Faist, T. (Eds.) (1997). Migration, immobility and development: Multidisciplinary perspectives. Oxford: Berg.

Hollifield, J. F. (2004). The emerging migration state. International Migration Review, 38(3), 885-891.

Karadağ, S. (2019). Extraterritoriality of European borders to Turkey: an implementation perspective of counteractive strategies. Comparative Migration Studies, 7. https://doi.org/10.1186/s40878-019-0113-y.

Kokott, J. (1997). Amuur v. France. American Journal of International Law, 91(1), 147-152.

Korzeniewicz, R. P., \& Moran, T. P. (2009). Unveiling inequality: A world-historical perspective. New York: Russell Sage Foundation.

Laube, L. (2019). The relational dimension of externalizing border control: selective visa policies in migration and border diplomacy. Comparative Migration Studies, 7. https://doi.org/10.1186/s40878-019-0130-x.

Leisering, B. (2016). Menschenrechte an den europäischen Aussengrenzen: Das Ringen um Schutzstandards für Flüchtlinge [Human rights at Europe's external borders: The struggles around protection standards for refugees]. Frankfurt a.M.: Campus.

Menjívar, C. (2014). Immigration law beyond borders: Externalizing and internalizing border controls in an era of securitization. The Annual Review of Law and Social Science, 10, 353-369.

Moyn, S. (2010). The last utopia: Human rights in history. Cambridge: Belknap Press of Harvard University Press.

Simmel (2001). Aufsätze und Abhandlungen 1909-1918 [Articles and essays 1909-1918], Band I. (Original essay published 1918). Frankfurt a.M.: Suhrkamp. Retrieved from https://www.suhrkamp.de/buecher/gesamtausgabe_in_24_baenden_2 8412.html.

Sylla, A., \& Schultz, S. U. (2019). Commemorating the Deadly Other Side of Externalized Borders. "Migrant-Martyrs", Sacrifices and Politizations of (Irregular) Migration on the International Migrants Day in Mali. Comparative Migration Studies, 7. https://doi.org/10.1186/s40878-019-0167-x

Triadafilopoulos, P. (2012). Becoming multicultural: Immigration and the politics of membership in Canada and Germany. Vancouver: University of British Columbia Press.

Tyzler, E. (2019). From controlling mobilities to control over women's bodies: gendered effects of EU border externalisation in Morocco. Comparative Migration Studies, 7. https://doi.org/10.1186/s40878-019-0128-4.

Üstübici, A. (2019). The impact of externalized migration governance on Turkey: Technocratic migration governance and the production of differentiated legal status. Comparative Migration Studies, 7. https://doi.org/10.1186/s40878-019-0159-x.

Vammen, I. M. S. (2019). New contested borderlands: Senegalese migrants en route to Argentina. Comparative Migration Studies, 7. https://doi.org/10.1186/s40878-018-0109-z.

Winters, N., \& Izaguirre, C. M. (2019). Es cosa suya: entanglements of border externalization and African transit migration in Northern Costa Rica. Comparative Migration Studies, 7. https://doi.org/10.1186/s40878-019-0131-9.

Zolberg, A. R. (2006). A nation by design: Immigration policy in the fashioning of America. New York: Russell Sage Foundation with Harvard University Press.

\section{Publisher's Note}

Springer Nature remains neutral with regard to jurisdictional claims in published maps and institutional affiliations. 